\title{
The Impact of Using Etymological Analysis on Teaching Vocabulary to EFL University Students
}

\author{
Effat Hosseini \\ Faculty of Letters and Humanities, Arak University, Iran \\ Email: e_hosseini_66@yahoo.com \\ Shahrzad Sarfallah \\ Faculty of Letters and Humanities, Arak University, Iran \\ Email: sf89shahrzad@yahoo.com \\ Fateme Bakhshipour \\ Faculty of Letters and Humanities, Arak university, Iran \\ Email: Fatima.bakhshipour@yahoo.com \\ Hamid Reza Dolatabadi \\ Faculty of Letters and Humanities, Arak University, Iran \\ Email: h_dowlatabadi@yahoo.com
}

\begin{abstract}
Being disappointed in retention of previously encountered vocabularies is one of the most reported displeasures that EFL students have faced during vocabulary acquisition so far. Since most of the English words descend from Greek and Latin roots, among the multitude of distinct strategies employed in teaching vocabulary, providing learners with an awareness of how existing words are able to be dismantled into different roots, not only generate the opportunity to let them discover the meaning of the words for themselves but also makes them capable of retrieving the targeted words easily. The present study, thus, aimed at exploring the very effect of teaching vocabulary to 59 participants who belonged to two intact classes. They were assigned to experimental and control groups. As far as the level of vocabulary proficiency was concerned, a pretest was administered to both groups. While the control group was going to acquire new words by means of dictionary, and through inferencing the meaning of unfamiliar words from text, the experimental group received treatment based on etymological analysis. After 6 weeks, an immediate posttest was administered to both experimental and control groups. The results were analyzed through one-way Analysis of Covariance (ANCOVA). Subsequently, a questionnaire was given to the experimental group in order to collect their opinions regarding the effectiveness of teaching vocabulary through etymology. Findings indicated that experimental group outperformed the control group. Consequently, the positive effect of this strategy and its implication in teaching vocabulary was manifested by opinions elicited from the experimental group.
\end{abstract}

Index Terms - vocabulary learning, etymology, retention, roots, dictionary learning

\section{INTRODUCTION}

Apparently, the power which words exercise not only on the realm of education but also on the individuals' daily lives cannot be neglected. This very strong influence of vocabularies has been also proved during the history of human life. Since our capability to cope with such complex social, political, and economical complex world can be accelerated through possessing a fair command of language skills, learners need to be armed by such greatest tools as rich, vast vocabulary size in order to be successful either in their education or generally in their lives (Pikulski and Templeton, 2004). But vocabulary is vast and untidy. There were attempts to systematize it by teaching semantic fields, super ordinates and hyponyms, notional/functional categories, etc., but ultimately vocabulary remains a big muddle (Swan, 1998).

Before the mid 1980s, vocabulary was considered a neglected area of second language learning and teaching (Meara, 1981). As Gough and Tunmer (1986) put, development of vocabulary is important and at the same time vastly ignored. However, the late 1990's offer a completely different picture. Vocabulary studies have received increased attention judging by the number of publication in the field, there are more empirical studies on vocabulary learning strategies.

According to Bogaards (2001), words constitute a major part of a language. In the EFL context specifically, a fairly large and comprehensive vocabulary size predicts and at the same time reflects high levels of reading achievement (Pikulski and Templeton, 2004). By the same token, one of the persistent findings in the field of second language learning and teaching is that the extent of students vocabulary knowledge relates strongly to their reading comprehension and overall academic success (Baumann and Ash, 2003). Thus vocabulary is considered as one of five 
major components of reading instruction that is essential for learners to be successful readers. According to The Report of the National Reading Panel (2000), "the importance of vocabulary knowledge has long been recognized in the development of reading skills. As early as 1924, researchers noted that growth in reading power relies on continuous growth in the word knowledge" (p.4).

In the history of vocabulary instruction, there exist distinct types of vocabulary instruction such as definition based instruction, context-as-a-clue instruction, and semantic mapping approach (Bleckley, 2006) besides keyword method, translation, semantic mapping, guessing meaning from the context, mnemonic devices, etc. Although several studies demonstrate that vocabulary can be acquired indirectly through reading, the main concern specifically in the present study is how vocabulary instruction through Latin or Greek roots makes a difference (Zimmerman, 1997).

The ability to guess the meaning of unfamiliar words in a text is an important skill as learning the words largely depends on information derived from texts and also their roots (Hassan, 2002). So, effective second language vocabulary learning, specifically through learning the Latin or Greek roots, is particularly important for English as foreign language (EFL) learners who frequently acquire lexicons despite years of formal study. Raptis (1997) believes that the systems of vocabulary learning in reading has not received as much attention in second language research as other aspects of reading and the instructors should pay more attention to teaching roots to help the students learn the words in their second language faster. Schmitt (2008), also believes that "overriding principle for maximizing vocabulary learning is to increase the amount of engagement learners have with etymological items, mainly the roots" (p.352).

It is ostensible that general academic achievement and specifically reading success of the students are dependent on vocabulary growth, but there are decades of negligence considering putting those findings into practice (Pikulski and Templeton, 2004). A handful of studies have found that vocabulary increases as a result of instruction. While several scholars have stressed the significance of direct vocabulary instruction and the teaching of vocabulary strategies, little research has been carried out regarding the effectiveness of teaching specific vocabulary strategies (Brown and Perry, 1991).

Trench (1998) stated that just few linguists regarded etymology as the main body of the word studies. Among different vocabulary learning strategies, the etymological analysis strategy is just beginning to receive attention in the field. It means presentation of vocabulary through their comprising roots has been a relatively less trodden path in the area of research. Thus the present study aimed at investigating whether teaching vocabulary through Greek and Latin roots is effective than learning through traditional way of dictionary learning.

\section{REVIEW OF THE LITERATURE}

Regarding the studies done so far, Paribakht and Wesch (1999) conducted a study in which they examined incidental learning of new vocabularies through the reading of thematically related texts on university EFL students. The purpose of the study was to investigate the way in which knowledge of vocabulary can be acquired as a by-product of reading comprehension. The researchers intended to specify the strategies, knowledge, and information employed by the learners when they faced new words while reading the texts. The results of the study revealed that learners had the tendency to ignore a large amount of new vocabulary they encountered. It was found that the main strategy which was used by the learners was inferencing.

Bellomo (1999), examined the effects of etymology instruction, which is teaching Latin roots on English as second or foreign language (ESOL) college learners who were came from both Latin-based and non Latin-based language backgrounds. The results of the study confirmed the advantage of etymology instruction strategy to learners whose first language (L1) were Latin-based. But generally either group of learners equally benefitted from explicit instruction of roots.

In another study, Baleghizadeh and Yousefpoori Naeim (2011) underwent a single-subject study in which they introduced semantic mapping strategy as a vocabulary presentation technique. The researchers employed two semantic mapping strategies and they believed that learners' retention will improve using these strategy. The findings of the study substantiated that semantic mapping strategy did help learners retrieve learned vocabularies better.

\section{THE PRESENT STUDY}

Since most of the English words descend from Greek and Latin roots, among the multitude of distinct strategies employed in teaching vocabulary, providing learners with an awareness of how existing words are able to be dismantled into different roots, not only generate the opportunity to let them discover the meaning of the words for themselves but also makes them capable of retrieving the targeted words easily.

This study aimed to examine the role of root learning in recognizing the meanings of new words, hypothesizing that this may affect positively on vocabulary learning.

Research Question

Is there a significant difference in learning vocabulary through etymological analysis and traditional way of dictionary learning? 


\section{METHOD}

\section{A. Participants}

Two intact classes were selected as participants of this study. These classes consisted of 59 participants. They were assigned to experimental $(\mathrm{n}=31)$ and control $(\mathrm{n}=28)$ groups. The participants were both male and female university students, ranging from 21 to 28 years of age. It is worth pointing out that all the students were native speakers of Persian.

\section{B. Instruments}

A multiple-choice test of vocabulary was designed for the purpose of the present study. Firstly, a multiple-choice test of vocabulary consisting of 38 items was developed. Secondly, these items were piloted with 30 students at the same level of original participants. Then, after data collection, the process of item analysis was carried out. Finally, the very difficult or easy items were discarded, some were modified, and the 30 remaining ones were used as the pre-test and post-test in this study for experimental and control groups before and after treatment and placebo. The reliability of the test was calculated through Cronbach Alpha formula ( $\mathrm{r}=0.84)$.

In addition, a questionnaire, which consisted of five statements, was designed in order to see the participants' opinions concerning the effectiveness of learning vocabulary through etymology and the quality of retention of learned vocabulary items. This survey focused on assessing the degree to which teaching and learning new vocabulary items through etymology affect the development of EFL learners' knowledge of lexicon and its retention in the passages of time.

\section{Material}

Six texts were selected to be used as a main material for both experimental and control groups concerning the level of students' proficiency in English. The texts with interesting topics were chosen from the book, "The World of Words: Vocabulary for College Students". Every passage presented a reading selection that included several words to learn followed by an exercise that tested students' understanding of words used in context. In addition, a pamphlet including the etymological analysis of the new words in the passages were also designed and used for the experimental group.

\section{Procedures}

The participants of this study were divided into two groups: experimental and control. The designed pretest of vocabulary was administered to the two groups to elicit evidence in order to compare with the posttest results. Then, the students of both groups received treatment and placebo respectively. That is, the experimental group received treatment on etymological analysis of vocabulary in six sessions during six weeks. They were asked to read the texts with unfamiliar vocabularies which could be dismantled into their Latin or Greek roots. The students of experimental group were also allowed to use a pamphlet including the etymological analysis of new words used in the passages. They were actually taught to learn unfamiliar words using their root meaning presented in the pamphlet. They were also asked to exercise the learned roots and their meaning giving examples of words with the same roots. On the other hand, control group received the same materials but was taught new vocabularies through traditional way of vocabulary teaching in six sessions. In other words, students in the control group were asked to infer the meaning of the unfamiliar words from the text or use dictionary to look them up. After six weeks, the experimental and control groups both were given the posttest of vocabulary to examine the consequences of the two different ways of vocabulary teaching. The post-test results were gathered and compared with those of pre-test. The analysis of data was carried out through SPSS software, version 15. Finally, after the administration of the posttest, a questionnaire was given to the participants in order to collect their opinions regarding the effectiveness of employing etymological analysis as a way of vocabulary leaning.

\section{E. Results}

A one-way between-groups analysis of covariance (ANCOVA) was conducted to compare the effectiveness of two different interventions designed to examine the effect of learning vocabulary through etymological analysis. The independent variable was the type of intervention (learning vocabulary through etymological analysis and learning vocabulary through dictionary use) and the dependent variable consisted of scores on the vocabulary test administered after the intervention was completed. Participants' pretest scores of the two groups experimental and control groups were used as the covariate in this analysis.

The 0.05 level of statistical significance was set at all statistical tests in the present study. The descriptive statistics was obtained to find out the mean scores of experimental and control group on the vocabulary test.

TABLE 1.

RESUlTs OF THE DESCRIPTIVE STATISTICS FOR DESCRIPTIVE STATISTICS Dependent Variable: Posttest Experimental and Control Group

\begin{tabular}{|l|l|l|l|}
\hline \multicolumn{2}{|c|}{ Dependent Variable: Posttest Experimental and Control Group } \\
\hline groups & Mean & Std. Deviation & N \\
\hline Exp & 22.6774 & 4.10193 & 31 \\
Cont & 16.8214 & 3.68233 & 28 \\
Total & 19.8983 & 4.86966 & 59 \\
\hline
\end{tabular}


Table 1 shows the mean scores of experimental and control group on the vocabulary test after the intervention. The experimental group had a mean of $22.67(\mathrm{SD}=4.10)$ whereas the control group had a mean of $16.82(\mathrm{SD}=3.68)$.

One-way between-groups analysis of covariance (ANCOVA) was conducted to see whether there was a significant difference between the experimental and control groups in terms of their posttest scores. Preliminary analysis were conducted to ensure that there was no violation of the assumptions of normality, linearity, homogeneity of variances, homogeneity of regression slopes, and reliable measurement of the covariate. The results are presented in Table 2, 3, and 4.

TABLE 2.

RESULTS OF LEVENE'S TEST OF EQUALITY OF ERROR VARIANCES Dependent Variable: Posttest of Experimental and Control Group

\begin{tabular}{|l|l|l|l|}
\hline F & df1 & df2 & Sig. \\
\hline .258 & 1 & 57 & .614 \\
\hline
\end{tabular}

Table 2 indicates that the Sig. value is $.614(\mathrm{p} \geq 05)$. This means that there was no violation of the assumption.

TABLE 3.

RESULTS OF TESTS OF BETWEEN-SUBJECTS EFFECTS

\begin{tabular}{|l|l|l|l|l|l|l|l|}
\hline Source & Type III Sum of Squares & df & Mean Square & F & Sig. & Partial Eta Squared \\
\hline Corrected Model & $1116.443^{\mathrm{a}}$ & 2 & 558.222 & 120.722 & .000 & .812 \\
Intercept & 128.584 & 1 & 128.584 & 27.808 & .000 \\
Pre Exp and Cont (covariate) & 611.935 & 1 & 611.935 & 132.338 & .000 \\
groups & 282.785 & 1 & 282.785 & 61.155 & .000 \\
Error & 258.946 & 56 & 4.624 & & \\
Total & 24736.000 & 59 & & & \\
Corrected Total & 1375.390 & 58 & & & \\
\hline
\end{tabular}

TABLE 4

RESUltS OF Estimated MARginal MEANS

\begin{tabular}{|c|c|c|c|c|}
\hline \multirow[b]{2}{*}{ groups } & \multirow[b]{2}{*}{ Mean } & \multirow[b]{2}{*}{ Std. Error } & \multicolumn{2}{|c|}{$95 \%$ Confidence Interval } \\
\hline & & & Lower Bound & Upper Bound \\
\hline Exp & $22.026^{\mathrm{a}}$ & .390 & 21.244 & 22.808 \\
\hline Cont & $17.543^{\mathrm{a}}$ & .411 & 16.719 & 18.367 \\
\hline
\end{tabular}

a. Covariates appearing in the model are evaluated at the following values: pretest of Experimental and Control group $=16.4915$.

Table 3 presents the main ANCOVA results. The Sig. value of the independent variable (groups) variable is .000 (p $<.05)$ which is less than .05. It means that there is a significant difference between the posttest scores of the experimental and control groups.

Table 4 also shows the results of the effect size as indicated by Partial Eta Squared value. Here, this value is .52 which is a large effect size according to Cohen's (1988 cited in Pallant, 2007) guidelines. This value also indicates how much of the variance in the dependent variable is explained by the independent variable. Here, independent variable can explain 52 percent of the dependent variable.

The other piece of information gained from Table 3 concerns the influence of the covariate. Here, the Sig. value of the covariate is .000 , which is less than .05 . So, there is a significant relationship between the covariate (pretest of both groups) and the dependent variable (posttest of both groups), while controlling for the independent variable (groups). Moreover, the result shows that the covariate can explain 70 percent of the variance in the dependent variable.

\section{CONCLUSION AND DisCUSSION}

The results indicated that there was a significant difference between the experimental and control groups in terms of their posttest scores. It means that learning vocabulary through the etymological analysis was more effective than the traditional way of dictionary learning. This result is in line with Bellomo's (1999) study in which learners, who benefited from explicit instruction of Latin roots, had improvement in their vocabulary knowledge.

The data collected from the questionnaire also indicated that 68 percent of the participants believed that after learning how to dismantle words into their roots, they could discover new words' meaning easily without using dictionary. Likewise, 63 percent of the participants stated that learning words through etymological analysis gave them more confidence in learning more English vocabulary items. Moreover, regarding the ease of retention of vocabulary, 72 percent of the participants were able to remember better the words that they have learned through etymological analysis. In the same vein, 66 percent of the participants pointed out that encountering an unknown word in a text, they could 
break it down to its roots and find meaning rather than looking it up in dictionary. Finally, 78 percent of the participants asserted that they could effortlessly retrieve the learned words even three weeks after receiving treatment.

On the basis of participants' opinions elicited from questionnaire, the advantage of employing etymological analysis as an independent technique for vocabulary teaching became apparent. Hence, it could be recommended that using such technique either by itself or along with other techniques mentioned in the literature can be helpful in the development of lexical knowledge of EFL learners.

It is worth mentioning that the results of this study cannot be generalized to all EFL learners in different conditions due to the limited number of participants and small number of treatment sessions. Furthermore, as mentioned earlier, few studies have been conducted regarding teaching etymology in the field of vocabulary teaching and learning. Thus, further research studies concerning vocabulary instruction are needed in the area of second/foreign language learning.

\section{ACKNOWLEDGEMENT}

The authors wish to thank Miss Najmeh Heydari Dehkordi for her great help and support.

APPENDIX

\section{Tables}

TABLE 1.

RESULTS OF THE DESCRIPTIVE STATISTICS FOR DESCRIPTIVE STATISTICS Dependent Variable: Posttest Experimental and Control Group

\begin{tabular}{|l|l|l|l|}
\hline groups & Mean & Std. Deviation & N \\
\hline Exp & 22.6774 & 4.10193 & 31 \\
Cont & 16.8214 & 3.68233 & 28 \\
Total & 19.8983 & 4.86966 & 59 \\
\hline
\end{tabular}

TABLE 2.

RESULTS OF LEVENE'S TEST OF EQUALITY OF ERROR VARIANCES

Dependent Variable: Posttest of Experimental and Control Group

\begin{tabular}{|l|l|l|l|}
\hline F & df1 & df2 & Sig. \\
\hline .258 & 1 & 57 & .614 \\
\hline
\end{tabular}

TABLE 3.

RESULTS OF TESTS OF BETWEEN-SUBJECTS EFFECTS

\begin{tabular}{|l|l|l|l|l|l|l|l|}
\hline Source & Type III Sum of Squares & df & Mean Square & F & Sig. & Partial Eta Squared \\
\hline Corrected Model & $1116.443^{\mathrm{a}}$ & 2 & 558.222 & 120.722 & .000 & .812 \\
Intercept & 128.584 & 1 & 128.584 & 27.808 & .000 & .332 \\
Pre Exp and Cont & 611.935 & 1 & 611.935 & 132.338 & .000 & .703 \\
(covariate) & 282.785 & 1 & 282.785 & 61.155 & .000 & .522 \\
groups & 258.946 & 56 & 4.624 & & \\
Error & 24736.000 & 59 & 58 & & & & \\
Total & 1375.390 & & & & \\
Corrected Total & & & & & \\
\hline
\end{tabular}

a. R Squared $=.812$ (Adjusted R Squared $=.805)$

TABLE 4.

RESULTS OF ESTIMATED MARGINAL MEANS

\begin{tabular}{|c|c|c|c|c|}
\hline \multirow[b]{2}{*}{ groups } & \multirow[b]{2}{*}{ Mean } & \multirow[b]{2}{*}{ Std. Error } & \multicolumn{2}{|c|}{$95 \%$ Confidence Interval } \\
\hline & & & Lower Bound & Upper Bound \\
\hline Exp & $22.026^{\mathrm{a}}$ & .390 & 21.244 & 22.808 \\
\hline Cont & $17.543^{\mathrm{a}}$ & .411 & 16.719 & 18.367 \\
\hline
\end{tabular}

a. Covariates appearing in the model are evaluated at the following values: pretest of Experimental and Control group $=16.4915$.

\section{Pretest and Posttest}

Name:

Time:

1. According to recent studies, finger print patterns can often reveal congenital health problems.
a. natural
b. usual
c. fortunate
d. horrible

2. The genocide of Americans during World War I resulted in over a million deaths.
a. suffering
b. sadness
c. murder
d. hunger

3. The girl's vivacious temperament and sense of fun made her popular at school. 
$\begin{array}{llll}\text { a. innocent } & \text { b. careless } & \text { c. young } & \text { d. lively }\end{array}$

4. The philanthropic work of the foundation benefits all sectors of society.



5. Psychologists believe that the human psyche is governed by primitive needs for food and love.
a. family
b. soul
c. terror
d. loneliness

6. Although germ theory was once laughed at, it is now considered a tenable explanation of how diseases spread.

$\begin{array}{llll}\text { a. logical } & \text { b. negative } & \text { c. desirable } & \text { d. ridiculous }\end{array}$

7. Since scandal has ruined many careers, public figures should be circumspect in their personal lives.

$\begin{array}{llll}\text { a. unfriendly } & \text { b. worried } & \text { c. cautious } & \text { d. busy }\end{array}$

8. The newspaper retracted its false statements about the political candidates.

a. was firm about b. discussed intelligently c. delayed slightly d. took back

9. Those who walk with their hand in their pockets may be perverse and critical of others.

$\begin{array}{llll}\text { a. unhappy } & \text { b. contrary } & \text { c. observant } & \text { d. lonely }\end{array}$

10. They had inadvertently left without paying the bill.

$\begin{array}{llll}\text { a. meticulously } & \text { b. accidentally } & \text { c. profoundly } & \text { d. presumably }\end{array}$

11. The malevolent criminal deliberately released poison into the water.

$\begin{array}{llll}\text { a. evil b. careless } & \text { c. thoughtful } & \text { d. smart }\end{array}$

12. Work on the building was impeded by severe weather.

$\begin{array}{lll}\text { a. ignored } & \text { b. inspected } \quad \text { c. blocked } & \text { d. postponed }\end{array}$

13. Researchers find that plants are beneficial to the quality of the indoor air.

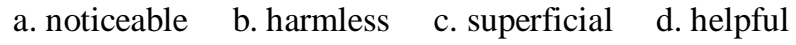

14. An increase in employment is an auspicious sign for the economy.

a. favorable b. noticeable c. reasonable d. detrimental

15. The brightly lit, large store was conspicuous on a street filled with dark buildings.

$\begin{array}{llll}\text { a. constant } & \text { b. noticeable c. enormous d. broad }\end{array}$

16. According to experts, money is the most common cause of discord in marriage.

$\begin{array}{llll}\text { a. poverty } & \text { b. hopelessness } & \text { c. disagreement } & d \text {. empathy }\end{array}$

17. My wife and my mother concur on the suit I should wear to the interview.

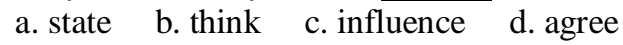

18. The student's appearance was not so reputable that we thought he was a beggar.

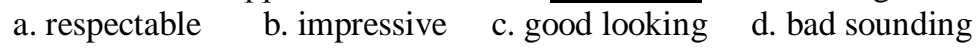

19. Since Thelma was gregarious, she liked to talk to client while she styled their hair.

$\begin{array}{llll}\text { a. intelligent } & \text { b. sociable } & \text { c. charming } & \text { d. untrustworthy }\end{array}$

20. Both houses of Congress congregated to hear the president's State of the Union address.

a. cheered b. accepted c. gathered d. socialized

21. Hundreds of flood victims have lost all their possessions and left destitute.

$\begin{array}{llll}\text { a. fearful } & \text { b. insane } & \text { c. unhappy } & \text { d. poor }\end{array}$

22. People were incredulous when told that the boy had survived for three years alone in the forest.

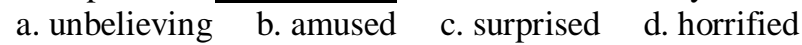

23. As the pretended heirs of Peter Wilks were disposing of his fortune, the veritable heirs arrived.

$\begin{array}{llll}\text { a. dreadful } & \text { b. true } & \text { c. sudden } & \text { d. slight }\end{array}$

24. Any deviation from this procedure would invite the invasion of the unlucky spirit.

$\begin{array}{llll}\text { a. benefit } & \text { b. rumor } & \text { c. change } & \text { d. noise }\end{array}$

25. The false prophet deluded people into thinking the world would end by New Year's Day.

a. helped b. advised c. frightened d. fooled

26. The equitable professor graded all students by the same standard.

$\begin{array}{lll}\text { a. fair b. good c. helpful d. strict } & \end{array}$

27. We find it incongruous when very rich people shop at discount stores.

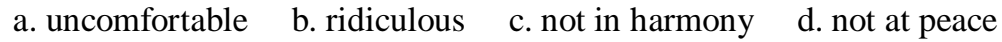

28. Modern human beings feel antipathy toward slavery.

$\begin{array}{lll}\text { a. fear b. hatred } & \text { c. poverty } & \text { d. pride }\end{array}$

29. Because the house wife kept her equilibrium, she was able to deal calmly with three crying children and a broken window.

$\begin{array}{llll}\text { a. comfort } & \text { b. confidence } \quad \text { c. balance } \quad \text { d. focus }\end{array}$

30. When I am on vacation, I revert to my old habit of sleeping late.

a. go forward b. go away c. go out d. go back

Reading passages

Passage: The Origins of Superstitions 
Why the number thirteen is considered unlucky? Why do people do who spill salt throw some over their shoulder? Are black cats evil? Can a mirror steal your soul? No scientist has verified these superstitions, yet many people once believed them without question. How did they originate?

The number thirteen has long been considered unlucky. According to legend, thirteen pins can make a dead spirit haunt a living person. A magician makes a doll that represents a living person and pierces it with thirteen needles. The doll is then placed on a grave, and a dead soul supposedly rises and haunts the unfortunate person represented by the doll.

(1)Thirteen was also believed to be a central number in the creed of witches. These supposedly evil souls were thought to refuse to obey God and to swear fidelity to the evil. Thirteen was the ideal number for a witches' coven, or meeting.

Many people considered Friday an unlucky day of the week because it was the day on which Christ was crucified. When Friday coincides with the thirteen of the month, we get an especially unlucky day. However, other Fridays have also been known as Black Friday, left many people destitute.

Unlike the number thirteen and Friday, salt was considered lucky. Because salt was used to preserve food, people believed that it would drive away bad spirits. However, spilling salt was thought to invite evil spirits. (3) In fact, dropping a salt container could make a nonchalant diner suddenly become frantic. There was only one way to avoid disaster: the diner had to take some salt into his right hand (the side of his lucky spirit) and throw it over his left shoulder (the side of his unlucky spirit). (4) Any deviation from this procedure would invite the invasion of the unlucky spirit, who was always lurking on the left.

Cats have held a special place in our superstitions. The mysterious ability of cats to survive falls from high places led the Egyptians worshiped cats.

(5) In contrast, cats have had a rather star-crossed (unlucky) fate in Europe. The fact that cats' eyes reflect light in the dark caused European people of the Middle Ages to think they were evil spirits. Cats were often pictured as witches' companions, and some people thought that, after seven years' service, a cat might even become a witch. Since black was the color of the devil, black cats inspired especially intense fear. God-fearing people walking at night might see a black cat cross their path. (6) Certain that they had seen a devil, they would break into a veritable panic. A cat that crossed from left to right was particularly frightening.

People often made ridiculous claims about cats. For example, in 1718 a man named William Montgomery claimed that two elderly women had been found dead in their beds on the morning after he had killed two noisy cats. (7) Montgomery deluded himself into thinking that the cats had been these women in disguise.

Such attitudes could lead to vicious persecution. Women who owned cats might be persecuted for witchcraft. Women of stage appearance were most likely to be accused; (8) however, at times, when quiet, nondescript women were accused of being witches.

A less harmful, though no less silly, superstition revolved around mirrors, which many people believed had magical powers. Perhaps you remember Snow White's stepmother asking her magical mirror. "Mirror, mirror on the wall. Who's the fairest one of all?" The ancients believed that breaking a mirror would bring seven years of bad luck, avoidable only if the pieces were quickly buried. The seven-year figure was given by the Romans, who thought that the human body renewed itself every seven years. Others believe that a mirror broke because bad spirits appeared in it. Throughout history, people have feared that a mirror would steal the weak soul of a sick person or a newborn. (9) Of course, this idea had no veracity, yet some people would not allow infants to see a mirror until they reached one year of age.

(10) Most modern people are incredulous when told of these superstitions. Yet some of us still believe that they have credibility. An occasional high-rise lacks a thirteenth floor; the numbers simply skip from twelve to fourteen. Some people throw salt over their left shoulders, even if it is a tongue-in-cheek (jokingly; insincerely) gesture or they no longer know why they are doing it. Perhaps you know somebody who shivers with fright when a black cat crosses a path at night and flashes its fiery eyes. Whatever the origin of superstitions, it's clear that some haunt us, even today.

\section{Exercise}

Each numbered sentence below corresponds to a sentence in the passage. Fill in the letter of the choice that makes the sentence mean the same thing as its corresponding sentence in the passage.

1. Thirteen was also believed to be a central number in the ___ of witches.
a. great harm
b. bad character
c. belief system
d. bad luck

2. A financial panic known as Black Friday left many people
a. fearful
b. insane
c. poor d. unhappy

3. In fact, dropping a salt container could make a ___ diner suddenly become frantic.
a. calm
b. hungry
c. horrified
d. pleasant

4. Any ___ fro this procedure would invite the invasion of the unlucky spirit.
a. change
b. benefit
c. rumor
d. noisy

5. Certain that they had seen a devil, they would break into a
a. dreadful
b. sudden
c. slight
d. true panic.

6. Montgomery __ himself into thinking that the cats had been these women in disguise.
a. helped
b. fooled
c. advised
d. frightened 
7. Even quiet, women were killed as witches.
a. peaceful acting
b. warm-hearted
c. very religious
d. ordinary looking

8. Of course, this idea had no
a. support
b. faith
c. belief
d. truth

9. Most modern people are when told of these superstitions.
a. unbelieving
b. amused
c. surprised
d. horrified

\section{Questionnaire}

\begin{tabular}{|c|c|c|c|}
\hline \multicolumn{2}{|r|}{$\begin{array}{l}\text { Name: } \quad \text { Gender: } \quad \text { Term: } \\
\text { Please read the items carefully. Put a tick under } \mathbf{1} \text { for "Yes", and } \mathbf{2} \text { for "No." Thank you very much } \\
\text { for your contributions. }\end{array}$} & ২ & 7 \\
\hline 1 & $\begin{array}{l}\text { After leaming how to dismantle words into their roots, I can discover new words' meaning } \\
\text { easily without using dict ionary. }\end{array}$ & & \\
\hline 2 & $\begin{array}{l}\text { Leaming words through etymological analysis gives me more confidence in learning more } \\
\text { English vocabulary it ems. }\end{array}$ & & \\
\hline 3 & I can remember better the words that I have leamed through etymological analysis. & & \\
\hline 4 & $\begin{array}{l}\text { Encountering an unknown word in a text, I try to break it down to its roots and find its } \\
\text { meaning rather than looking it up in dictionary. }\end{array}$ & & \\
\hline 5 & $\begin{array}{l}\text { The words that I have leamed through etymological analysis ret ain in my mind better and } \\
\text { longer than those I have memorized through dictionary. }\end{array}$ & & \\
\hline
\end{tabular}

\section{REFERENCES}

[1] Baleghizadeh, S., \& Yousefpoori Naeim. M. (2011). Enhancing vocabulary retention through semantic mapping: A singlesubject study. The International Journal of Language Society and culture. (32), 11-6.

[2] Baumann, J.F., Kame'enui, E.J., \& Ash, G. (2003). Research on vocabulary instruction: Voltaire redux. In J. Fllod, D. Lapp, J.R. Squire., \& J. Jenson. (Eds.), Handbook of research on teaching the English Language Arts (2 $2_{\text {nd }}$ ed.).Mahwah, NJ: Lawrence Erlbaum.

[3] Bellomo, T. S. (1999). Etymology and vocabulary development for the L2 college student. Teaching English as a Second or Foreign Language, 4(2).

[4] Bleckey, B. (2006). Rethinking vocabulary instruction. Retrieved February 15, 2012 from Pedagogy in practice: http://www.pedagogypractice.blogspot.com/feeds/posts/default?orderby=updated

[5] Bogaards, P. (2001). Lexical units and the learning of foreign language vocabulary. Studies in Second Language Acquisition, 23, 321-43.

[6] Brown, T. S., \& Perry, F. L. Jr. (1991). A comparison of three learning strategies for ESL vocabulary acquisition. TESOL Quarterly, 25(1), 17-32.

[7] Gough, P. B. \& Tunmer, W. E. (1986). Decoding, reading, and reading disability. Remedial and Special Education, 7, 6-10.

[8] Hassan, F. (2002). Developing competent readers. In M.K. David, \& F. Hashim. (Eds.), Developing reading skills (pp.107-139). Malaysia: Sasbadi Sdn. Bhd. http://www.pedagogypractice.blogspot.com/2006/12/rethinkingvocabulary- instruction.html

[9] Meara, P. (1981). Vocabulary Acquisition: A neglected aspects of language learning. Language Teaching and Linguistics Abstract, 14, 221-46.

[10] National Reading Panel. (2000). Report of the National Reading Panel: Teaching children to read. Washington, D.C.: National Institute of Child Health and Human Development.

[11] Paribakht, T. S., \& M. Wesche. (1999). Reading and incidental L2 vocabulary acquisition: An introspective study on lexical inferencing. Studies in Second Language Acquisition (21), 195-224.

[12] Pikulski, J., \& Templeton, Sh. (2004). Teaching and developing vocabulary: Key to long-term reading success. Retrieved February 15, 2012 from www.eduplace.com

[13] Raptis, H. (1997). Is second language reading vocabulary best learned by reading? Canadian Modern Language Review, 53, 566-80.

[14] Schmitt, N. (2008). Instructed second language vocabulary learning. Language Teaching Research, 12, 329-63.

[15] Swan, M. (1998). Seven bad reasons for teaching grammar - and two good ones. English Teaching Professional, 7, 3-5.

[16] Trench, R. (1998). The study of words. London: John Parker.

[17] Zimmerman, C. B. (1997). Do reading and interactive vocabulary instruction make a difference? An empirical study. TESOL Quarterly, 31, 121-40.

Effat Hosseini is an MA student of Teaching English as a Foreign Language (TEFL) in Arak University, Iran. She obtained her B.A. in English Translation in Shahrekord University, Iran. Her main areas of interest are Interlanguage Pragmatics, Critical Thinking, and Critical Discourse Analysis. 
Shahrzad Sarfallah was graduated from Media School majoring news translation. She is currently M.A. student of TEFL at Arak University. She is interested in Critical Discourse Analysis, Critical Thinking, and vocabulary instruction.

Fateme Bakhshipour is an MA student of Teaching English as Foreign Language (TEFL) at Arak University, Iran. She finished her B.A. in English Translation in Zanjan University, Iran. Her main research interests are Critical Thinking, Reading Comprehension, and Critical Discourse Analysis.

Hamid Reza Dolatabadi has taught language and Discourse studies in different academic schools in England and Iran. Publishing papers in International journals, he has also presented in many conferences worldwide. His main interest is in the analysis of discourse specifically in virtual environments. 